\title{
CCR7 deficiency causes diarrhea associated with altered ion transport in colonocytes in the absence of overt colitis
}

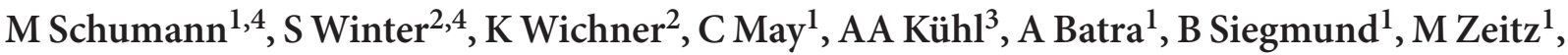 \\ J-D Schulzke ${ }^{1}$, M Lipp $^{2}$ and UE Höpken ${ }^{2}$
}

The chemokine receptor CCR7 is a central regulator in the maintenance of cellular homeostasis of mucosal tissues. $\mathrm{CCR}^{-/-}$mice develop autoimmune gastritis and exocrinopathy accompanied by the formation of mucosal tertiary lymphoid follicles. Here we found that CCR7-deficient mice frequently suffered from chronic diarrhea linked with increased gastrointestinal motility and the development of severe anorectal prolapse. Enhanced formation of intestinal lymphoid follicles was associated with an elevated proportion of activated colonic T cells and increased production of the cytokine interleukin (IL)-1 $\beta$. To uncover the pathomechanisms of diarrhea in CCR7 $7^{-/-}$mice, colonic epithelial barrier and ion channel activities were analyzed in Ussing chambers. Although overt acute colitis was absent, CCR7 deficiency resulted in reduced electrogenic sodium absorption and colonic chloride secretion. As it is known that IL-1 $\beta$ regulates epithelial sodium channel (ENaC) activity, these data imply a causal link between CCR7 expression, IL-1 $\beta$ level, and $\mathrm{Na}^{+}$ malabsorption owing to altered $\mathrm{ENaC}$ expression and diarrhea.

\section{INTRODUCTION}

The mucosal surfaces of the gastrointestinal (GI) tract represent one of the largest lymphoid compartments in the body. Although the mucosal immune system is essential for protecting the host against infectious and toxic assaults, it must simultaneously ignore commensal organisms and dietary antigens. Uncontrolled immune reactions against commensal bacteria, innocuous antigens, or host epithelial cells can lead to autoimmune disease such as chronic inflammatory bowel disease. ${ }^{1-4}$

The inductive compartment-presumed to sample antigens from mucosal surfaces to stimulate cognate naive $\mathrm{T}$ and B lymphocytes-includes the organized mucosa-associated lymphoid tissue, whereas the effector compartment consists of the lamina propria, the stroma of exocrine glands, and the intestinal epithelial lining. ${ }^{5}$ However, the interplay between lymphoid follicles as a hallmark structure of the mucosa-associated lymphoid tissue and the intestinal epithelia as one of the major effector sites is not well understood.

The CCR7 knockout $\left(\mathrm{CCR}^{-1-}\right)$ mice are a well-characterized model to study the function of tertiary lymphoid follicles (TLFs) in cellular mucosal homeostasis, as loss of CCR7 induces formation of tertiary lymphoid follicles throughout the GI mucosa. CCR7, which is known to be a major lymph-node homing receptor for lymphocytes and dendritic cells, facilitates the induction of adaptive immune responses as well as homeostatic lymphocytic recirculation. ${ }^{6-8}$ Dysregulation of immune homeostasis and adaptive immunity in CCR7 ${ }^{-1-}$ mice is associated with induction of autoimmunity, ${ }^{9}$ especially autoimmune gastritis (AIG). ${ }^{10}$

In the present study, we demonstrate that lack of CCR7 is also associated with chronic diarrhea, suggesting a dysregulation of intestinal mucosal homeostasis. Most often, diarrhea secondary to an activation of the mucosal immune system goes along with a breakdown of the epithelial barrier leading to leak-flux diarrhea. ${ }^{11}$ However, other etiologies for diarrhea, e.g., specific bacterial toxins, endocrinopathies, conditions of malassimilation, neuropathies, and neoplastic diseases, induce secretory or osmotic pathomechanisms that are not primarily associated with epithelial cell death. ${ }^{12,13}$

This work presents evidence for an immune-mediated condition (i.e., tertiary lymphoid follicle formation in $\mathrm{CCR}^{-1-}$

\footnotetext{
${ }^{1}$ Medical Clinic I, Campus Benjamin Franklin, Charité-Universitätsmedizin Berlin, Berlin, Germany. ${ }^{2}$ Department of Tumor Genetics and Immunogenetics, Max-DelbrückCenter for Molecular Medicine (MDC), Berlin, Germany. ${ }^{3}$ Department of Pathology/Research Center ImmunoSciences (RCIS), Charité-Universitätsmedizin Berlin, Berlin, Germany. ${ }^{4}$ These authors contributed equally to this work. Correspondence: UE Höpken (uhoepken@mdc-berlin.de) 
mice) causing a dosed immune response of pro-inflammatory cytokines, resulting in the modulation of ion channel activities on enterocytes and in a $\mathrm{Na}^{+}$-malabsorptive type rather than a leak-flux type of diarrhea.

\section{RESULTS}

$\mathrm{CCR}^{-/-}$mice frequently develop an anorectal prolapse and exhibit reduced whole-gut transit time but no differences in epithelial resistance

$\mathrm{CCR}^{-1-}$ mice frequently suffered from nonbloody, chronic diarrhea, which was emphasized by the fact that $34 \%$ of the $\mathrm{CCR}^{-1-}$ animals $(n=50)$ developed a severe anorectal prolapse within 2-12 months of age (as compared with only a single Wt mouse out of 35 animals (2.9\%)) (Figure 1a). Secondly, the whole-gut transit time reflecting GI motility was significantly reduced in $\mathrm{CCR}^{-1-}$ mice when compared with Wt mice (Figure 1b).

It was shown earlier that $\mathrm{CCR} 7^{-1-}$ mice develop moderate multi-organ autoimmunity accompanied by the formation of lymphoid aggregates at mucosal sites. ${ }^{9,14}$ Recently, we characterized an inflammatory milieu in the gastric mucosal tissue of $\mathrm{CCR}^{-1}$ mice that supported the development of autoimmune gastritis in these animals. ${ }^{10}$ Secretion of mucosal inflammatory cytokines has also been linked to an altered epithelial barrier function. ${ }^{15,16}$ Hence, we aimed to resolve an association of the observed clinical features with possible changes in epithelial barrier function. To differentiate the contribution of the epithelial and subepithelial mucosal compartment to barrier function, alternating current impedance spectroscopy was performed on colonic specimens obtained from 8-12-weekold Wt and CCR7 ${ }^{-1-}$ mice. However, the epithelial resistance $\left(R^{\mathrm{e}}\right)$ of CCR7 $7^{-1-}$ mice was not significantly different compared with Wt littermates (Figure 1c). In contrast to $R^{\mathrm{e}}$, the subepithelial resistance $\left(R^{\mathrm{s}}\right)$ was found to be significantly (1.4-fold) higher in $\mathrm{CCR}^{-1-}$ mice, accounting for a higher transmural resistance $\left(R^{\mathrm{t}}\right)$. Most likely, this is explained by the increased cellularity present in the subepithelial tissue of CCR7 $7^{-1-}$ compared with Wt mice (Figure 1d,e). Importantly, the mucosal surface area, determined by crypt width, length, and number, was not significantly different in Wt and CCR $7^{-1-}$ mice (data not shown).

\section{Accelerated formation of isolated lymphoid follicles (ILFs) in the large intestine of CCR7-deficient mice}

We previously reported that the mucosal tissue of $\mathrm{CCR} 7^{-1-}$ mice is highly permissive for the formation of lymphoid aggregates, which develop into ectopic follicular structures particularly in the stomach and lung. ${ }^{14}$ Here we further characterized an accelerated development of ILFs in the large intestine of $\mathrm{CCR}^{-1-}$ mice. Histological analysis of 8-12-week-old mice revealed that all CCR7 ${ }^{-1-}$ mice developed ILFs that were increased in size and number (Figure 1d,e). For the most part, the cellular composition of CCR7 ${ }^{-/-}$ILFs was comparable to that found in the smaller and less frequently observed ILFs of Wt mice. Thus, all ILFs were rich in B cells, whereas T cells were scattered not only within these lymphoid structures, but also throughout the whole lamina propria (LP) of the colon (Figure 2a). Small clusters of macrophages and single neutrophils adjacent to ILFs were observed in CCR7 $7^{-1-}$ mice and, in some cases, also in Wt controls (Supplementary Figure S1 online). However, no active neutrophil-dominated inflammation was present in $\mathrm{CCR} 7^{-1-}$ or Wt mice. Mast cells that can also potentially contribute to an acute inflammatory colitis ${ }^{17-21}$ have not been detected in the colonic LP of CCR7 $7^{-1-}$ or $\mathrm{Wt}$ mice (Supplementary Figure S2 online).

The number of $\mathrm{CD} 3^{+} \mathrm{T}$ cells within the $\mathrm{LP}$, aside of the ILFs, was also increased in CCR $7^{-1-}$ compared with $\mathrm{Wt}$ mice (Figure 2b). Additionally, enhanced numbers of apoptotic activated caspase3-positive cells were found in the LP of $\mathrm{CCR}^{-1-}$ compared with Wt mice (Figure 2c), suggesting an enhanced cellular turnover in CCR7 ${ }^{-l}$ mice. The amount of epithelial periodic acid-Schiff-positive goblet cells was mildly decreased (Figure 2d), probably owing to some displacement of goblet cells by expansion of ILFs in CCR7 $7^{-/-}$mice. By contrast, the number of intraepithelial $\mathrm{CD}^{+} \mathrm{T}$ cells or activated caspase3-positive lymphocytes was comparable in $\mathrm{Wt}$ and CCR7 ${ }^{-1-}$ mice (Figure 2e,f), underlining that increased lymphoid cellularity was limited to the LP and submucosa, and did not occur intraepithelially.

\section{$\mathrm{CCR7}^{-/-}$mice exhibit increased serum immunoglobulin (Ig)G and IgM titers against colonic antigen and contain increased numbers of Foxp $3^{+}$regulatory T cells (Tregs) within ILFs compared with Wt mice}

CCR7-deficient mice frequently displayed large ILFs with surprisingly high numbers of Foxp $3^{+}$Tregs within and adjacent to these lymphoid structures (Figure 3a). By contrast, ILFs of Wt mice contained only single Foxp $3^{+}$Tregs (Figure 3a). We quantified the total amount of Tregs within the LP of the large intestine in 12-week-old animals. Flow cytometry analysis revealed strongly increased numbers of LP Foxp $3^{+}$ Tregs in CCR $7^{-1-}$ ( > 10-fold) compared with Wt mice (Figure 3b). Additionally, we determined serum titers of autoantibodies directed against colonic antigen. Colonic antigen-specific IgG and IgM titers were significantly increased in CCR $7^{-1}$ - compared with Wt mice (Figure 3c,d). Serumderived anti-colonic IgM antibodies of CCR7 $7^{-1-}$ mice were specifically directed to colonic enterocytes (Figure 3d; right panel), indicating a humoral autoimmune response against the intestinal epithelial layers in CCR7-deficient mice.

\section{Expression of activation markers on intestinal T cells and colonic production of interleukin (IL)-1 $\beta$ are increased in CCR7 ${ }^{-/-}$mice}

T-cell activation is associated with high expression of CD69 and CD44 and low expression of CD62L. We analyzed the activation status of CCR7-deficient colon-resident lymphocytes in comparison with Wt lymphocytes by flow cytometry. The early activation antigen CD69 was expressed on $48.6 \pm 3.2 \%(n=4)$ of colonic mucosa-derived CD4 ${ }^{+}$and $92.3 \pm 1.1 \%(n=4)$ of CD $8^{+}$ CCR7 $^{-1-}$ T lymphocytes compared with $35.2 \pm 1.1 \%(n=4)$ of colonic-derived $\mathrm{CD}^{+}$and $81.7 \pm 6.2 \%(n=4)$ of $\mathrm{CD} 8^{+} \mathrm{Wt}$ 

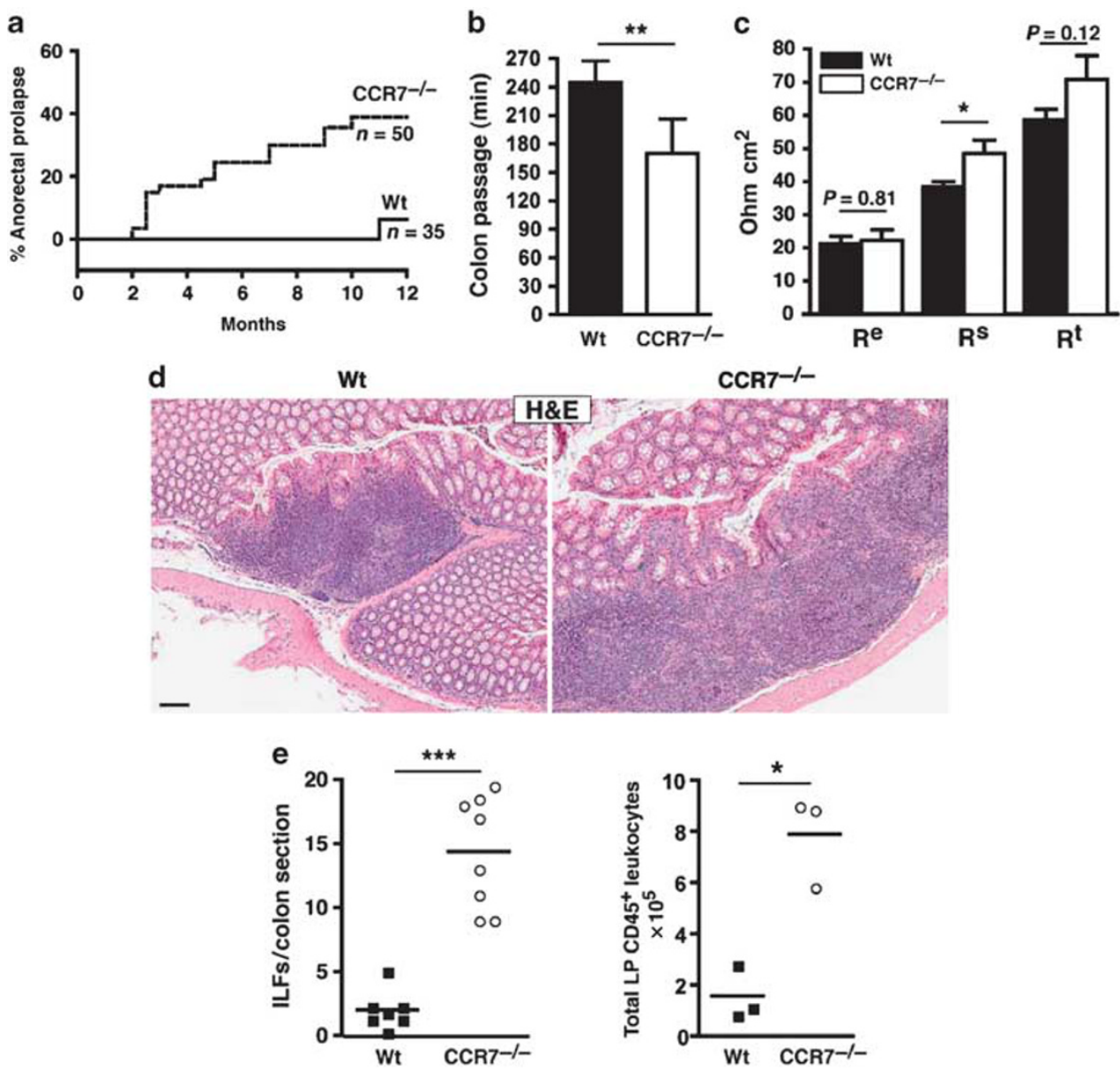

$\mathrm{CCR7}^{-1-}$
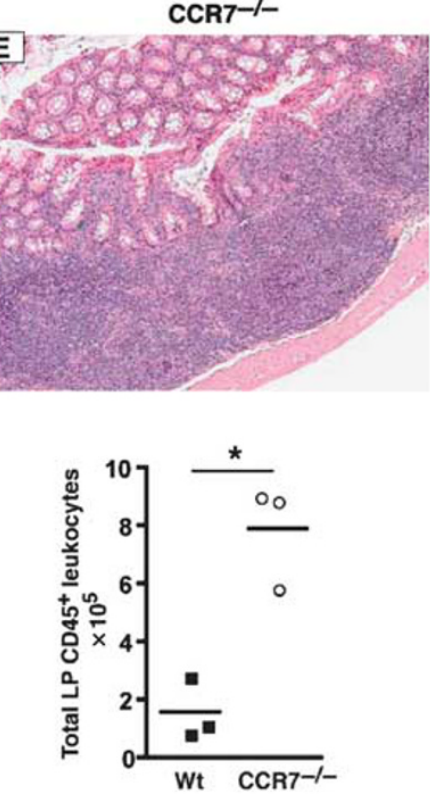

Figure $1 \mathrm{CCR} 7^{-/-}$mice frequently develop an anorectal prolapse, exhibit reduced whole-gut transit time, and enhanced colonic lymphoid aggregates. (a) In all, 34\% of CCR7 ${ }^{-/-}$mice (dotted line; $n=50$ ) developed a severe anorectal prolapse within $2-12$ months of age. Only 1 out of 35 wild-type (Wt) mice (straight line) developed an anorectal prolapse at 11 months of age. (b) Whole-gut transit time was reduced in CCR7-/- (open bars; $n=5$ ) compared with Wt (black bars; $n=5$ ) mice. One representative experiment of two independent experiments is shown. Bars represent means \pm s.d. ${ }^{* *} P<0.01$; Mann-Whitney test. (c) Impedance spectroscopy revealed a higher subepithelial resistance in stripped colon tissue of 10-12-week-old CCR7-/- $(n=4$; open bars) compared with Wt $(n=6$; black bars) mice. Bars represent means \pm s.e.m. * $P<0.05$; unpaired Student's $t$ test. (d) Paraffin-embedded sections of the large intestine of 8-12-week-old Wt or CCR7 ${ }^{-/-}$mice ( $n=6-7$ per group) were stained with hematoxylin and eosin (H\&E; one representative animal of each group is shown). Bar $=100 \mu \mathrm{m}$. (e) The number of colonic isolated lymphoid follicles (ILFs) was quantified based on two sections of each animal (Wt: black squares, $n=8$; CCR7 ${ }^{-1-}$ : open circles, $n=8$; left panel) and total numbers of colonic lamina propria (LP)-derived CD45+ leukocytes were quantified by flow cytometry (Wt: black squares, $n=3$; CCR7 ${ }^{-1-}$ : open circles, $n=3$; right panel). ${ }^{\star} P<0.05,{ }^{* * *} P<0.001$; Mann-Whitney test.

T lymphocytes (Figure 4a). The percentage of $\mathrm{CD} 69^{+} \mathrm{CD} 4^{+}$ and $\mathrm{CD} 8{ }^{+} \mathrm{T}$ cells that co-expressed a second activation marker, CD44, was also increased in the CCR7 ${ }^{-/-}$compared with Wt mice (Figure $4 \mathbf{b}$ ), but the difference was not statistically significant. However, the increase in the numbers of total activated $\mathrm{CD} 4^{+}$and $\mathrm{CD} 8^{+} \mathrm{T}$ cells in $\mathrm{CCR} 7^{-/-}$mice was more profound than the relative (percentage) increase of activated $\mathrm{T}$ cells, as CCR7-deficient mice have more $\mathrm{CD}^{+} \mathrm{T}$ cells in the LP (Figure 2b).

Whole-organ cultures of the transverse and distal parts of the colon were assayed for the secretion of the inflammatory Thelper (Th)1-type associated cytokines interferon- $\gamma($ IFN- $\gamma$ ), IL-6, tumor-necrosis factor (TNF)- $\alpha$, IL-1 $\beta$, and IL-15, and for the Th2-type-associated cytokines IL- 4 and IL-13. CCR7-/mice revealed a significant increase in colonic IL- $1 \beta$ production
(Figure 4c). We identified $\mathrm{CD} 11 \mathrm{c}^{+}$dendritic cells within the colonic lymphoid aggregates as the major cellular source of IL-1 $\beta$ production (Figure $4 \mathbf{d}$ ) and their total numbers were substantially increased in CCR $7^{-1-}$ mice (Figure 4d). Th 17 effector T-cell responses (marked by IL-17 production) were also elevated; however, statistical significance was not reached (Supplementary Figure S3c online). No substantial differences were observed for colonic protein levels of IL-6, TNF- $\alpha$, and IFN- $\gamma$ (Supplementary Figure S3a, b, and $\mathbf{d}$ online) and the Th2 cytokines IL- 4 and IL-13 were at the detection limit in both Wt and CCR7 ${ }^{-1-}$ mice (data not shown). Colonic IL-15 levels, a cytokine that exerts a complex function by mediating deleterious as well as protective effects on intestinal epithelia, ${ }^{22,23}$ were substantially decreased in CCR7 ${ }^{-1}$ compared with Wt mice (Figure 4e). Taken together, colon-infiltrating lymphocytes and 

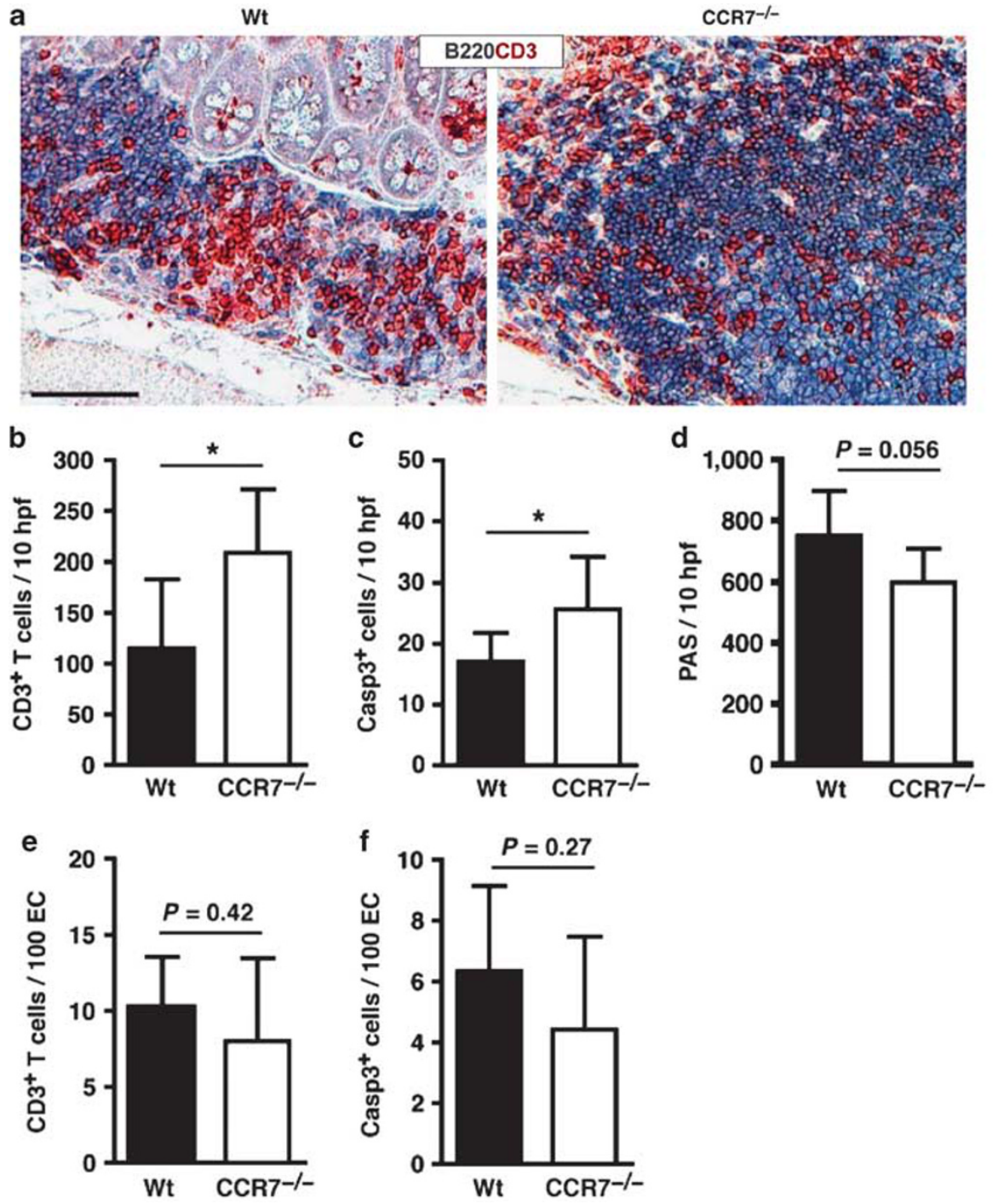

Figure 2 Lack of CCR7 causes an increase in lamina propria (LP) but not in intraepithelial T lymphocytes. (a) Paraffin-embedded sections of the large intestine of 8-12-weeks-old wild type (Wt) or CCR7 ${ }^{-1-}$ mice ( $n=6-7$ per group) were immunohistochemically stained for $\mathrm{B}$ (B220 in blue) and $\mathrm{T}$ (CD3 in red) cells. Representative stainings are shown. Bar $=100 \mu \mathrm{m}$. (b) Mean number of LP CD3 ${ }^{+} \mathrm{T}$ lymphocytes/10 high-power fields (hpf) and of caspase $3^{+}$cells $/ 10 \mathrm{hpf}$ (c) in colon sections of Wt ( $n=6$; black bars) and CCR7 ${ }^{-/-}$( $n=7$; open bars). (d) Colonic tissues of both groups were stained with periodic acid-Schiff (PAS) reagent and PAS staining was quantified based on two sections of each Wt $\left(n=6\right.$; black bars) and CCR7 ${ }^{-/-}$mouse ( $n=7$; open bars). (e) Mean number of intraepithelial CD3 ${ }^{+}$T lymphocytes/100 epithelial cells (EC) and of caspase $3^{+}$cells $/ 100 \mathrm{EC}(\mathrm{f})$ in colon sections of Wt ( $n=6$; black bars) and CCR $7^{-1-}\left(n=7\right.$; open bars). Bars represent means \pm s.d. ${ }^{*} P<0.05$; Student's $t$ test.

dendritic cells support a chronic inflammatory intestinal milieu in CCR7-deficient mice.

\section{$\mathrm{CCR7}^{-/-}$mice exhibit downregulated colonic chloride secretion and decreased cystic fibrosis transmembrane conductance regulator (CFTR) mRNA levels compared with Wt mice}

It has been described that inflammatory stimuli, i.e., IL-1 $\beta$, TNF- $\alpha$, and IFN- $\gamma$, can affect intestinal barrier function ${ }^{15,16}$ and also can change the balance between fluid absorption and secretion of the intestinal epithelium. ${ }^{24,25}$ Here we analyzed electrogenic chloride secretion in the Ussing chamber across isolated mucosa of distal colon segments taken from 10-12- week-old Wt and CCR7-1- mice. CCR7-deficient mice displayed reduced chloride secretion compared with Wt animals (Figure 5a). Because colonocytes exert apical chloride secretion mostly via the CFTR, ${ }^{26}$ we quantified the expression level of CFTR mRNA in distal colon segments of 4- and 8-week-old Wt and $\mathrm{CCR}^{-1-}$ mice by quantitative real-time PCR analysis. In line with the downregulation of $\mathrm{Cl}^{-}$secretion in $\mathrm{CCR}^{-1-}$ mice, we observed reduced CFTR mRNA levels in colonic tissues of CCR7 ${ }^{-1-}$ compared with Wt mice (Figure 5b). As CCR7 ${ }^{-1-}$ mice showed a normal mucosal surface area, downregulation of $\mathrm{Cl}^{-}$secretion is not merely linked to a reduced number of epithelial cells. Hence, we suggest that the impaired chloride secretion is associated with reduced CFTR expression. 

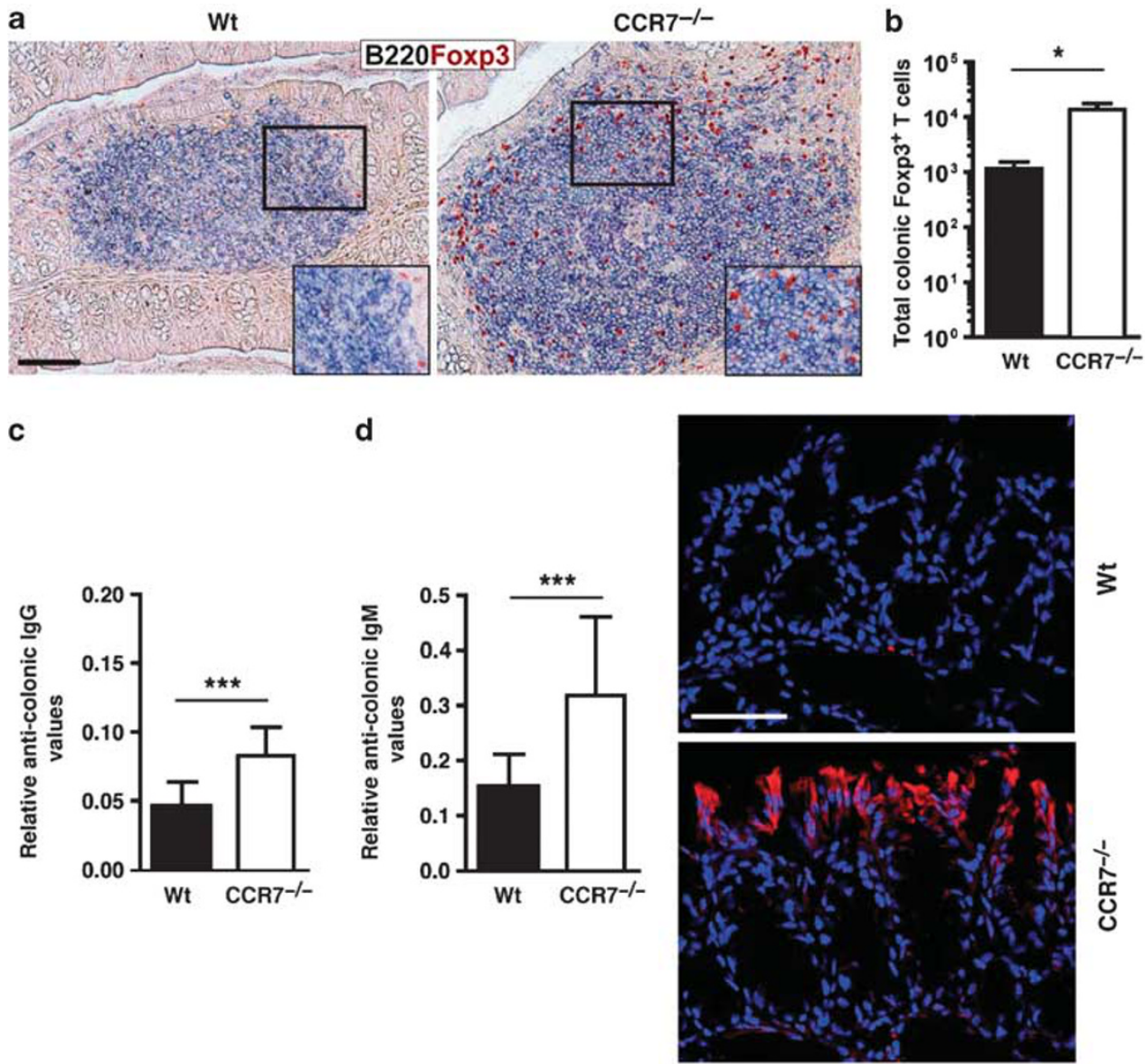

Anti-colonic IgM

Figure $3 \mathrm{CCR} 7^{-/-}$mice show increased regulatory T cells (Tregs) within isolated lymphoid follicles and enhanced colonic antigen-specific immunoglobulin (Ig) G and IgM serum levels. (a) Paraffin-embedded sections of the large intestine of 8-12-week-old Wt or CCR7-/- mice ( $n=6-7$ per group) were immunohistochemically stained for Treg cells (Foxp3 in red) and B cells (B220 in blue). Representative sections are shown. Enlarged magnification of representative areas in the insets. Bar $=100 \mu \mathrm{m}$. (b) Arithmetic means of the absolute lamina propria (LP) Foxp3 ${ }^{+}$Treg cells of wild-type (Wt) (black bars; $n=4$ ) and CCR7 ${ }^{-1-}$ (open bars; $\left.n=6\right)$ mice. Data were calculated from flow cytometry analysis of CD4 ${ }^{+}, \mathrm{CD}^{2} 5^{+}$, and Foxp $3^{+}$expression by size-gated LP cells. ${ }^{*} P<0.05$; Mann-Whitney test. Relative serum (c) IgG and (d) IgM (left panel) autoantibody titers directed against colonic-derived antigen of 8-12-week-old Wt (black bars) and CCR7-/- (open bars) mice. Sera were used at a dilution of 1:50. Absorbance values at $450 \mathrm{~nm}$ represent the relative anti-colonic IgG or IgM. Bars represent means \pm s.d.; ${ }^{* * \star} P<0.001$, Mann-Whitney test. (d, right panel) Serum of $\mathrm{CCR}^{-/-}(n=5)$ but not of Wt mice $(n=5)$ reacted with enterocytes in cryosections of the large intestine analyzed by immunofluorescence staining. For immunofluorescence stainings, cryosections were incubated with mouse serum diluted 1:50. Binding of circulating lgM to the tissue was detected with rat anti-mouse IgM antibody (red). Representative sections are shown.

\section{$\mathrm{CCR}^{-1-}$ mice displayed reduced electrogenic sodium transport after aldosterone induction and decreased $\alpha-, \beta-$, and $\gamma$-epithelial sodium channel $(\mathrm{ENaC})$ subunit mRNA levels}

The rate-limiting factor for sodium absorption along the large intestine is the amiloride-sensitive ENaC. First, we measured $\mathrm{ENaC}$ activity by determining aldosterone-induced, amiloridesensitive short circuit current $\left(I_{\mathrm{sc}}\right)$, expressed as monovalent cation flux $\left(J_{\mathrm{Na}}\right)$. In Wt colon mucosa, aldosterone induced a strong increase in $I_{s c}$, which dropped again after administration of amiloride (Figure 6a, left panel). By contrast, CCR7 ${ }^{-1-}$ colon mucosa showed a much lower increase in $I_{\text {sc }}$ after aldosterone treatment and accordingly the amiloride-sensitive drop was also smaller in comparison with Wt mice (Figure 6a, left panel). Next, we analyzed whether colonic ENaC mRNA expression was altered in $\mathrm{CCR7}^{-1-}$ mice. Colonic ENaC mRNA expression of the $\alpha$ - and $\beta$-ENaC subunit was significantly reduced in $\mathrm{CCR}^{-1-}$ mice compared with Wt controls (Figure 6b). Overall, electrogenic sodium transport as well as $\alpha_{-}, \beta-$, and $\gamma$-ENaC subunit mRNA expression levels were lower in colon specimens of CCR7 ${ }^{-/-}$mice. Given the increased IL-1 $\beta$ expression in $\mathrm{CCR} 7^{-/-}$mice, we next analyzed the capacity of IL-1 $\beta$ to reduce $\mathrm{ENaC}$ function. Rat late distal colon was mounted in Ussing chambers and $\mathrm{ENaC}$ activity was measured after induction with aldosterone of the mucosae in the presence of IL-1 $\beta$ (Figure 7a,b). As previously published, IL-1 $\beta$ significantly reduced $\mathrm{ENaC}$-associated cation flux by $72 \% .{ }^{24}$ We further evaluated the signal transduction pathway that-when activated by IL- $1 \beta$-induces the downregulation of ENaC. Since we and the others have previously implicated extracellular signal-regulated 

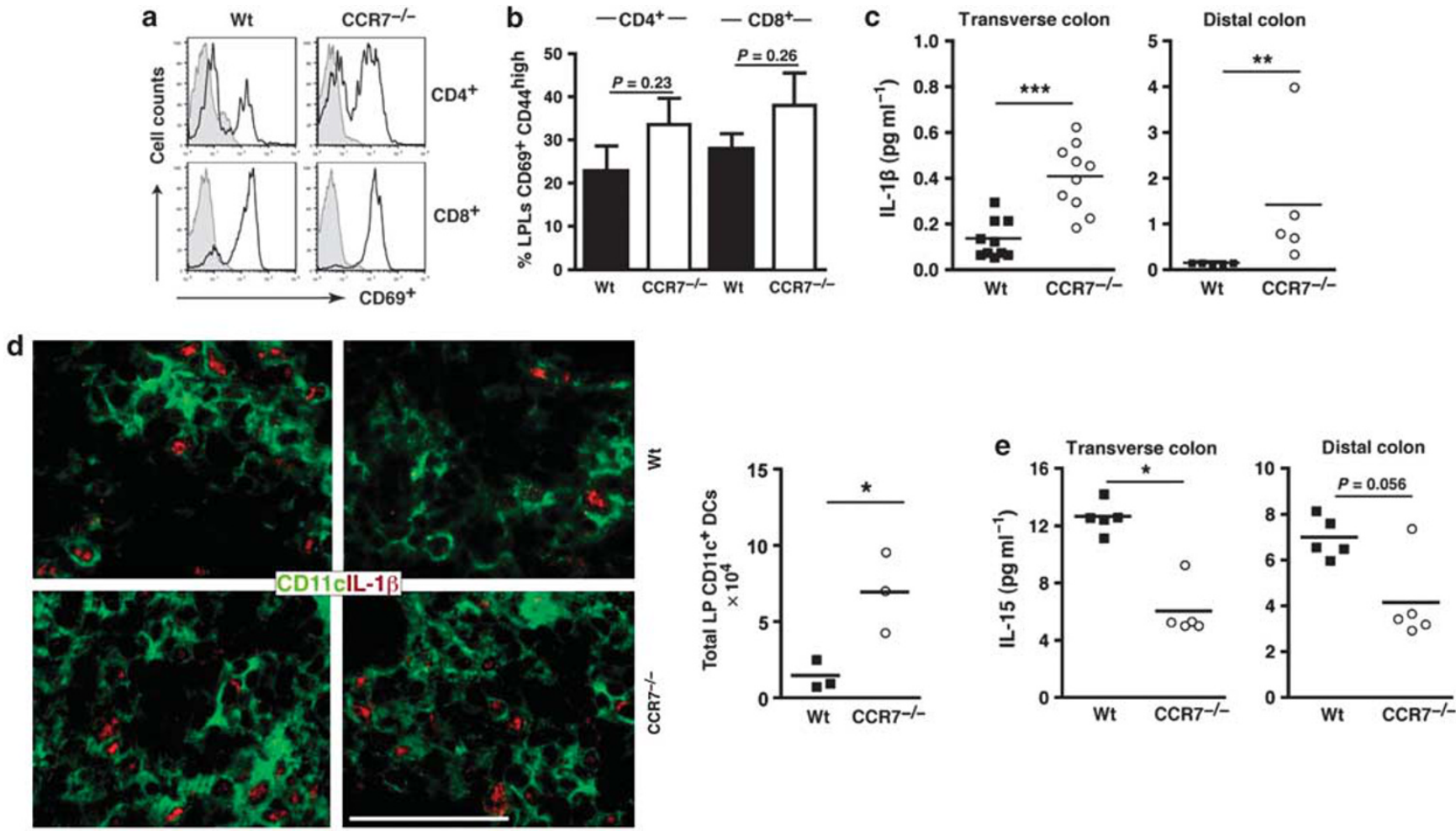

Figure 4 Enhanced expression of activation markers on colonic immune cell subsets and altered colonic cytokine expression in CCR7 ${ }^{-/-}$mice. (a) Colonic lamina propria (LP) leukocyte (LPL)-derived T-cell subsets (gated on CD4 ${ }^{+}$or CD8 ${ }^{+}$) of 8-12-week-old CCR7 ${ }^{-/-}(n=4)$ and Wt mice $(n=4)$ were stained for CD69 expression (black curve) and analyzed by flow cytometry (shaded curve: isotype control). A representative example of each group is shown. (b) Percentages of colonic LPL-derived activated CD69+ CD44high T cells of Wt (black bars) and CCR7 ${ }^{-/-}$(open bars) mice $(n=4$ per group) are shown. Bars represent means \pm s.d. (c) Determination of interleukin (IL)-1 $\beta$ secretion from the transverse (left panels; $n=10$ per group) and the distal (right panels; $n=5$ per group) part of the colon of 8-12-week-old Wt and CCR7 ${ }^{-/-}$mice. Colonic sections were cultured for $22 \mathrm{~h}$ in RPMI 1640 medium w/o serum at $37^{\circ} \mathrm{C}$. IL- $1 \beta$ release was measured in supernatants by cytokine bead array and normalized to colon weight. (d) Colon sections of Wt and CCR7 ${ }^{-1-}$ mice were double stained for $\mathrm{CD} 11 \mathrm{c}^{+}$cells (green) and IL-1 $\beta$-expressing cells (red). Shown are representative stainings of colonic lymphoid follicular aggregates in 2 out of 3-4 mice analyzed per group. Bar $=100 \mu \mathrm{m}$. The total numbers of colonic LPL-derived CD11 ${ }^{+}$ dendritic cells (DCs) were quantified by flow cytometry (Wt: black squares, $n=3$; CCR7 ${ }^{-1-}$ : open circles, $n=3$ ). (e) Determination of IL-15 secretion from the transverse (left panels; $n=5$ per group) and distal (right panels; $n=5$ per group) parts of the colon of $8-12$-week-old Wt and CCR7 ${ }^{-/}-$mice. Colonic sections were cultured for $22 \mathrm{~h}$ in RPMI 1640 medium w/o serum at $37^{\circ} \mathrm{C}$. IL- 15 release was measured in supernatants by enzyme-linked immunosorbent assay. ${ }^{\star} P<0.05,{ }^{\star \star} P<0.01,{ }^{\star \star \star} P<0.001$; Mann-Whitney test.

kinase (ERK) and p38 signaling to be involved in $\mathrm{ENaC}$ regulation, rat colon mucosae were preincubated with specific inhibitors (U0126, $10 \mu \mathrm{M}$ for ERK and SB202190, $10 \mu \mathrm{M}$ for p38). ${ }^{27,28}$ Both inhibitors reversed the IL- $1 \beta$-induced reduction of $\mathrm{ENaC}$ current, although they had-when applied in the absence of IL-1 $\beta$ - no effect on ENaC activity.

\section{DISCUSSION}

In a recent study, we demonstrated that mice that lack CCR7 develop an early spontaneous autoimmune gastritis. ${ }^{10}$ This was associated with the formation of lymphoid aggregates at mucosal GI sites including the stomach, colon, and lung. ${ }^{9,14}$

In the present study, we show that CCR7 $7^{-/-}$mice suffer from chronic diarrhea leading to frequent anal prolaps and to a reduced whole-gut transit time. Interestingly, chronic diarrhea in CCR7 ${ }^{-1-}$ mice was present in the absence of overt colitis. CCR7 ${ }^{-1}$ - mice exhibited increased colonic lymphoid cellularity with enlarged isolated ILFs. These aggregates consisted mainly of B and T lymphocytes and small clusters of macrophages. This is contrary to transgenic mouse models, i.e., IL-2 ${ }^{-1-}$ mice, which develop diarrhea owing to an acute intestinal inflammation with infiltration of the gut mucosa by lymphocytes, plasma cells, and granulocytes, expression of a variety of pro-inflammatory cytokines, as well as ulcerations and crypt abscesses. ${ }^{29}$ Consistent with the lack of an acute mucosal inflammation, the pro-inflammatory cytokines IL- 6 , TNF- $\alpha$, and IFN- $\gamma$, frequently associated with colitis induction, ${ }^{30,31}$ were not found to be elevated in CCR7 ${ }^{-1-}$ colon mucosa. Moreover, no experimental evidence was found that mast cells or mast-cell-derived cytokines, which have been associated with acute inflammation in inflammatory bowel disease, ${ }^{20,32}$ contributed to chronic diarrhea in CCR7 ${ }^{-1-}$ mice.

By contrast, secretion of the pro-inflammatory cytokine IL- $1 \beta$ was significantly increased in CCR7 $7^{-/-}$mice. This is in agreement with our recent finding that local gastric IL- $1 \beta$ expression is enhanced in naive CCR7 $7^{-1-}$ mice, whereas other 

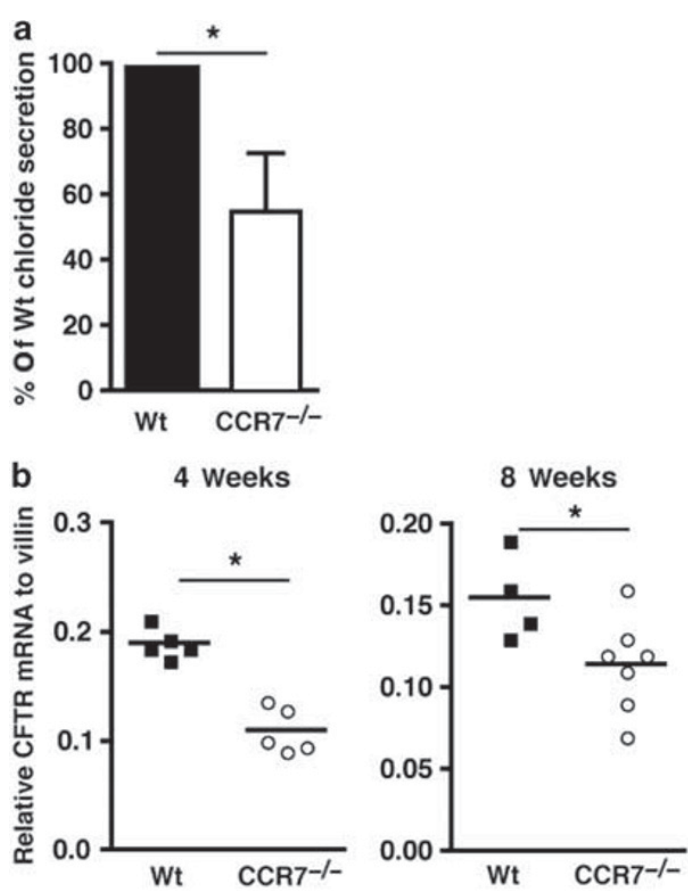

Figure $5 \mathrm{CCR}^{-/-}$mice exhibit downregulated colonic chloride secretion and decreased cystic fibrosis transmembrane conductance regulator (CFTR) mRNA levels compared with Wt mice. (a) Colons of 10-12-week-old Wt (black bars; $n=8$ ) and $\mathrm{CCR}^{-/}$(open bars; $n=8$ ) mice were mounted in Ussing chambers and electrogenic chloride secretion was measured as $\Delta l_{\mathrm{sc}}$ after stimulation with theophylline $(10 \mathrm{mM})$ and prostaglandin $\mathrm{E}_{2}(2.8 \mathrm{nM})$. Bars represent means \pm s.e.m. ${ }^{\star} P<0.05$; Student's $t$-test. (b) Quantification of mRNA expression of CFTR by real-time quantitative reverse transcription PCR in distal colonic samples of 4 week- and 8-week-old CCR7 ${ }^{-/-}$(open circles) compared with $\mathrm{Wt}$ (black squares) mice. Data are normalized to villin expression and expressed as means. ${ }^{\star} P<0.05$; Mann-Whitney test.

pro-inflammatory cytokines are unaltered. ${ }^{10}$ Previous studies regarding the effect of $\mathrm{T}$ cell-induced colonic inflammation on bowel dysfunction indicated that activated intestinal $\mathrm{T}$ cells can damage the epithelial barrier through cytokine-mediated pathways even before histological signs of acute inflammation emerge. ${ }^{33,34}$

IL-15, a cytokine that is constitutively expressed by a variety of cell types, including macrophages and intestinal epithelial cells, ${ }^{35}$ was found to be decreased in the CCR7 ${ }^{-1-}$ colon mucosa. Previous work on IL-15 points to a complex role of this cytokine in epithelial cell function. On the one hand, IL-15 appears to have a deleterious effect on epithelia in T cell-mediated small intestinal diseases like celiac sprue, where it sensitizes epithelia to natural killer cell receptor-mediated cell death by epithelial overexpression of the atypical major histocompatibility complex molecule class 1 related chain A. ${ }^{22,23}$ However, another report showed endogenous IL-15 to protect colonocytes from apoptosis in chronic colitis. ${ }^{36}$ Hence, in certain clinical situations a reduction in local IL-15 expression might even add to the pathology.

Intestinal homeostasis and regulation of intestinal inflammatory responses have been associated with regulator
Treg-mediated control mechanisms. ${ }^{37-39}$ Here we detected numerous Tregs within the colonic ILFs of $\mathrm{CCR}^{-1-}$ mice and an overall increase in the total colonic Treg cell numbers compared with Wt controls. This is again consistent with what we found in the gastric mucosal tissue of CCR7 $7^{-1-}$ mice and most likely reflects the inability of CCR7-deficient Tregs to recirculate properly through tissue-associated lymph nodes. ${ }^{10}$ Hence, Tregs are present in large numbers but do not efficiently support maintenance of GI homeostasis.

What additional mechanism other than an acute inflammation might contribute to diarrhea in $\mathrm{CCR} 7^{-1-}$ mice? Data presented herein suggest that the downregulation of the sodium-absorbing $\mathrm{ENaC}$ has a prominent role. $\mathrm{ENaC}$ is expressed at the apical epithelial cell membrane, causing water resorption secondary to absorption of luminal sodium. ${ }^{40} \mathrm{ENaC}$ expression and function are known to be reduced in patients with ulcerative colitis (UC), ${ }^{41}$ an inflammatory bowel disease leading to severe chronic diarrhea. As IL- $1 \beta$ was the only proinflammatory cytokine found to be profoundly elevated in CCR7 ${ }^{-1-}$ mice, it is of special interest that IL- $1 \beta$ preincubation of healthy murine colon mucosa is already known to reduce $\mathrm{ENaC}$ activity. ${ }^{24}$ Similar to what we found in $\mathrm{CCR} 7^{-1-}$ mice, this is elicited by the downregulation of ENaC mRNA. ${ }^{24}$ The importance of $\mathrm{ENaC}$ activity in concentrating stool was recently highlighted by the work of Bergann et al. ${ }^{42}$ that uncovered the mechanisms for the induction of $\mathrm{ENaC}$ activity as a driving force for the rapid anti-diarrheal response after corticosteroid treatment in patients with acute exacerbations of inflammatory bowel disease.

To unravel the signaling pathway underlying the downregulation of $\mathrm{ENaC}$ activity after IL- $1 \beta$ stimulation, specific inhibitors for ERK and p38 kinase signaling pathways were employed. ERK signaling has previously been identified as a mediator of IL-1 $\beta$-related $\mathrm{ENaC}$ depression in middle-ear epithelial cells, whereas p 38 has been suggested as being central to $\mathrm{ENaC}$ regulation in alveolar epithelial cells..$^{28,43}$ Our results revealed a role for both $\mathrm{ERK}$ and $\mathrm{p} 38$ kinase in $\mathrm{ENaC}$ regulation. These data also showed a partial overlap with a study by Zeissig et al. ${ }^{27}$ on TNF- $\alpha$-induced downregulation of ENaC in intestinal epithelial cells, as this pathway was also dependent on ERK signaling.

At first sight, the finding that electrogenic chloride secretion and CFTR activity are reduced in CCR $7^{-1-}$ mice appears to be in contradiction to the fact that these mice suffer from diarrhea. However, similar results were previously presented for ulcerative colitis in human samples, where $\mathrm{ENaC}$ downregulation is found in parallel with reduced CFTR activity. ${ }^{15,41}$ Furthermore, basal (i.e., unstimulated) $I_{\mathrm{sc}}$ values, most likely reflecting chloride secretion, were also shown to be diminished. ${ }^{41}$ Therefore the pathophysiology of these forms of diarrhea appears not to be associated with an increased chloride secretion, but rather with a reduction in sodium absorption.

In vitro studies by Cafferata et al. ${ }^{44}$ presented an interesting dual role of IL- $1 \beta$ in the induction of CFTR expression. They found an increased CFTR mRNA and protein expression when T84 cells were treated with low amounts of IL- $1 \beta$, but downmodulation of CFTR by IL-1 $\beta$ treatment at high doses. 

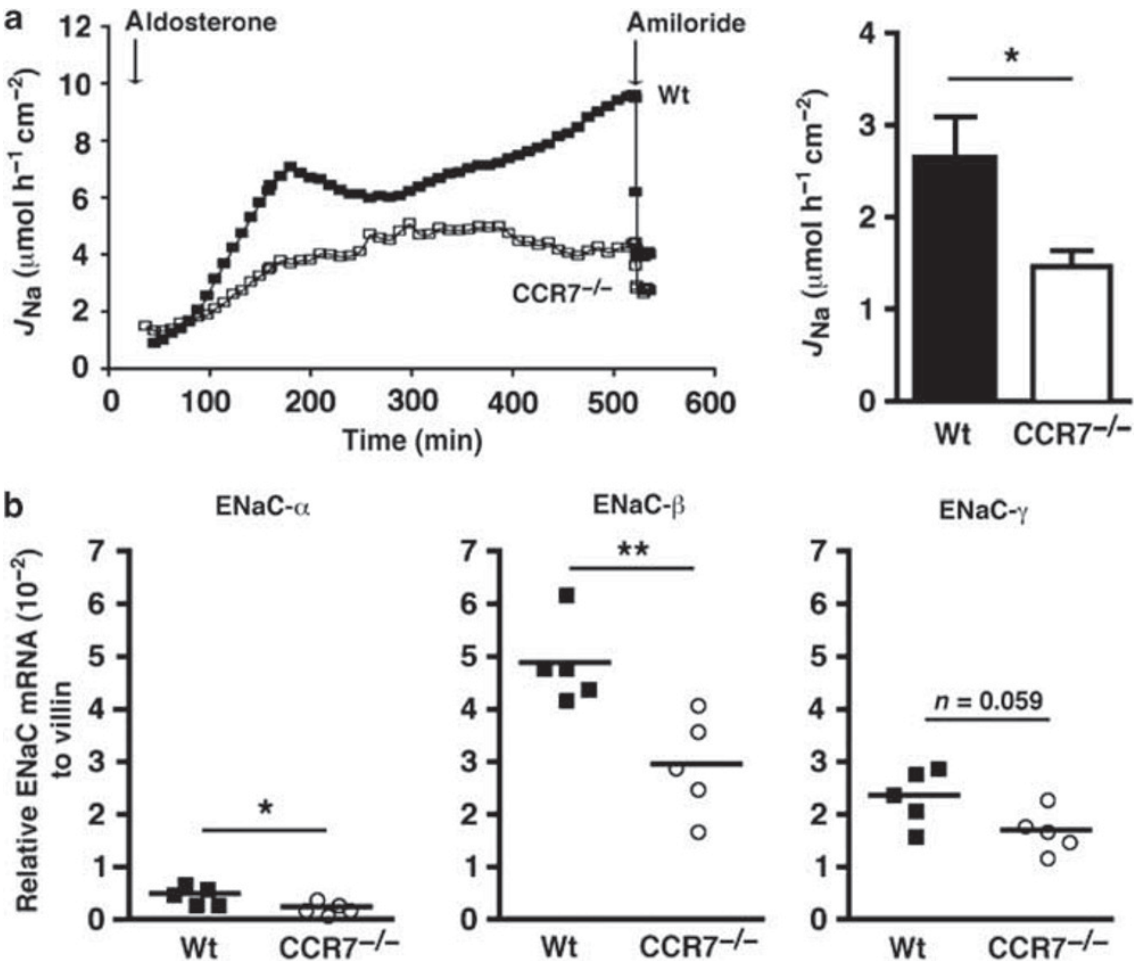

Figure $6 \mathrm{CCR}^{-/-}$mice exhibited decreased $\alpha-, \beta$-, and $\gamma$-epithelial sodium channel (ENaC) subunit mRNA levels and reduced electrogenic sodium transport. (a) Colons of 10-12-week-old CCR7 ${ }^{-/-}$(open squares and open bars; $n=10$ ) and Wt (black squares and black bars; $n=8$ ) mice were mounted in Ussing chambers. Electrogenic sodium transport was measured as monovalent cation flux $\left(\mu \mathrm{molh}^{-1} \mathrm{~cm}^{-2}\right)$ after induction of ENaC by aldosterone and consecutive inhibition by amiloride. The course of monovalent cation flux $\left(J_{\mathrm{Na}}\right)$ of a representative Ussing experiment after addition of aldosterone is shown to the left. Averaged monovalent cation fluxes are shown in the bar diagram to the right. Bars represent means \pm s.e.m. ${ }^{\star} P<0.05$; unpaired Student's $t$ test. (b) Quantification of mRNA expression of the ENaC ion channel subunits ENaC- $\alpha,-\beta$, and $-\gamma$ by real-time quantitative reverse transcription PCR in distal colonic samples of 8-week-old CCR7-/- $(n=5$; open circles) compared with Wt ( $n=5$; black squares) mice. Data are normalized to villin expression and expressed as means. ${ }^{*} P<0.05$ and ${ }^{* \star} P<0.01$; unpaired Student's $t$ test.

In line with the data of our study, increased IL- $1 \alpha$ and IL-1 $\beta$ levels have also been found in the non-inflamed mucosa of Crohn's disease patients. ${ }^{45}$ The authors showed that colonic IL- $1 \alpha$ and IL-1 $\beta$ are increased not only in the inflamed mucosa but also in the non-inflamed mucosa, suggesting continuous activation of the intestinal immune system. ${ }^{45} \mathrm{CCR}^{-1-}$ mice, as mentioned earlier, revealed increased GI IL- $1 \beta$ secretion without evidence of an acute neutrophil-dominated mucosal inflammation. Furthermore, a continuous activation of the intestinal immune system in CCR7 ${ }^{-1-}$ mice was indicated by an increased proportion of activated $\mathrm{CD} 69^{+} \mathrm{CD} 44^{+} \mathrm{CD} 4^{+}$and $\mathrm{CD} 69^{+} \mathrm{CD} 44^{+} \mathrm{CD} 8{ }^{+} \mathrm{LP} \mathrm{T}$ lymphocytes.

Another human disease where elevated IL- $1 \beta$ levels are associated with a watery diarrhea is familial Mediterranean fever, a periodic fever syndrome. In familial Mediterranean fever, a mutation in the MEFV (Mediterranean fever) gene encoding the protein pyrin causes dysfunction of the inflammasome. This results in elevated IL- $1 \beta$ levels elicited by a complex dysregulation of the inflammasome in monocytes. ${ }^{46}$ Notably, familial Mediterranean fever patients frequently suffer from diarrhea without showing manifestation of colitis, ${ }^{47}$ suggesting that modulation of ion channel activity via IL- $1 \beta$ might also be relevant.
Chronic diarrhea is associated with altered GI motility and gut transit time. GI motility dysfunction has been connected with disturbed GI physiology, including altered epithelial, muscle, intestinal, and enteric neural function. ${ }^{48}$ Hence, a contribution of neuromuscular dysfunction to the reduced gut transit time could also be inferred in CCR7 $7^{-1-}$ mice. Two recent studies on burn injury and on small-bowel graft transplantation in rats linked increased intestinal cytokine levels, i.e. IL- $1 \beta$, with delayed intestinal transit. ${ }^{49,50}$ In contrast, for Th17 immune activation it was reported that IL-17 enhances muscle cell contractility in mice. ${ }^{48}$ In our model it remains elusive if inflammatory cytokines can directly affect gut motility, as in $\mathrm{CCR}^{-1-}$ mice colonic expression of both IL-1 $\beta$ and IL-17 is enhanced.

In conclusion, we have demonstrated that in CCR7-deficient mice activated $\mathrm{T}$ cells are capable of modulating the activity of luminal ion channels in colonocytes, which results in the development of diarrhea. This adjusted T-cell response includes crossreactivity to intestinal antigen(s) and results in substantially enhanced IL-1 $\beta$ and IL-17 secretion. As a consequence, expression of ion channels on colonocytes is modulated, leading to a reduced net ion transport and colonic fluid accumulation. As this is found in the absence of acute inflammation, the CCR $7^{-1-}$ 

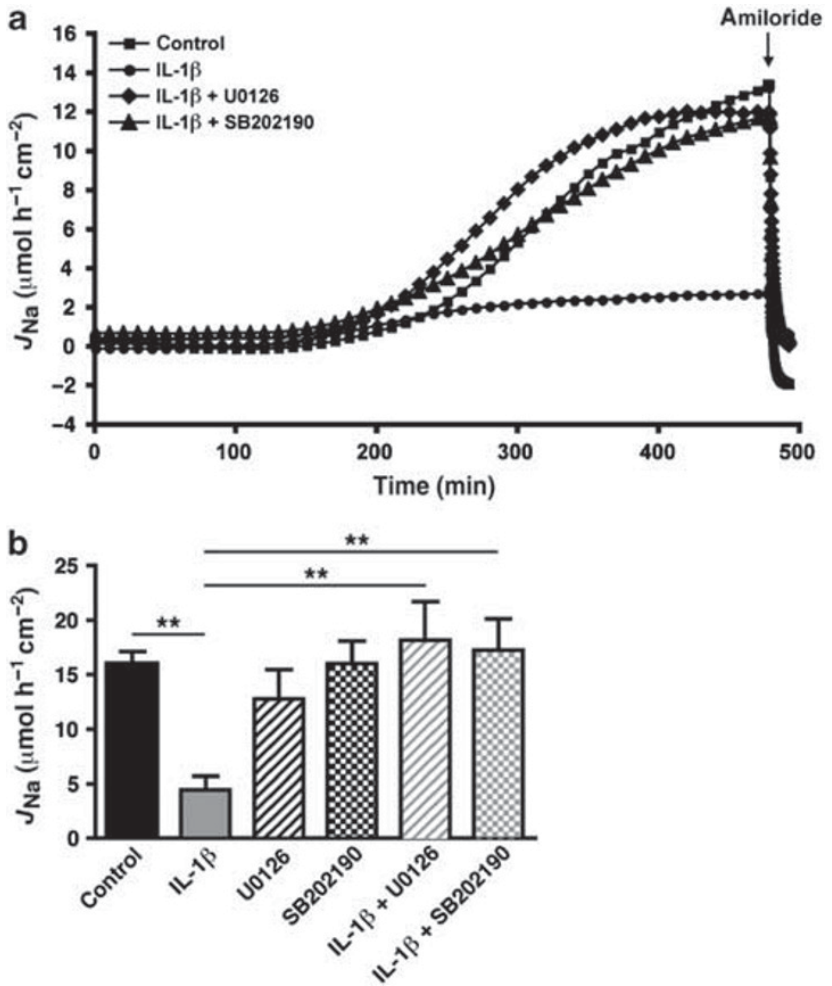

Figure 7 Interleukin (IL)-1 $\beta$-elicited signaling is dependent on mitogen-activated protein kinase (MAPK) activation. Rat late distal colon was mounted in Ussing chambers. Signaling inhibitors of mitogenactivated protein kinase/ERK kinase 1/2 (U0126, $10 \mu \mathrm{M})$ and p38 MAPK (SB202190, $10 \mu \mathrm{M}$ ) were added for $1 \mathrm{~h}$ to both chamber sides followed by addition of rat IL-1 $\beta\left(10 \mathrm{ng} \mathrm{ml}^{-1}, 10 \mathrm{Ung}^{-1}\right)$ to the serosal chamber side for $6 \mathrm{~h}$. Electrogenic sodium transport was measured as monovalent cation flux $\left(J_{\mathrm{Na}} ; \mu \mathrm{molh}^{-1} \mathrm{~cm}^{-2}\right)$ after induction of epithelial sodium channel $(\mathrm{ENaC})$ by aldosterone $\left(3 \times 10^{-9} \mathrm{M}, 8 \mathrm{~h}\right)$ and consecutive inhibition by mucosally added amiloride. (a) The course of monovalent cation flux of a representative Ussing experiment after addition of aldosterone is shown. (b) Averaged $J_{\mathrm{Na}}(n=6)$ values are shown in the bar diagram. Bars represent means \pm s.e.m. ${ }^{\star \star} P<0.01$; unpaired Student's $t$-test.

model points to an alternative pathophysiological mechanism for diarrhea.

\section{METHODS}

Mice. C57BL/6 mice were obtained from Charles River (Sulzfeld, Germany). CCR7 ${ }^{-1-}$ were generated as described ${ }^{6}$ and backcrossed onto a C57BL/ 6 background for 12 generations. Animals were housed in a specific pathogen-free facility at the Max-Delbrück-Center for Molecular Medicine, Berlin, Germany. All animal studies were performed according to institutional and Berlin State guidelines (registered under LaGeSo 0184/04 and 0371/05).

Immunohistology and histological evaluation. The following primary antibodies were used: goat anti-mouse CD3 (Santa Cruz, Heidelberg, Germany), polyclonal rabbit anti-human CD3 (Dako, Hamburg, Germany), PE-labelled rat anti-mouse IgM, Alexa Fluor 488-labelled hamster anti-mouse $\mathrm{CD} 11 \mathrm{c}$, and biotinylated rat anti-mouse B220 (BD Biosciences, Heidelberg, Germany), polyclonal rabbit anti-mouse cleaved caspase3 (Cell Signalling, Danvers, MA), biotinylated rat antiF4/80 and rat anti-mouse B220 (Biolegend, Uithoorn, The Netherlands), polyclonal goat anti-mouse IL-1 (R\&D Systems, Wiesbaden, Germany), biotinylated rat anti-mouse Foxp3, and purified rat anti-mouse Ly-6G (eBioscience, Frankfurt, Germany). Secondary antibodies included: goat anti-rat-IgG biotin conjugated and donkey anti-rat-IgG biotin conjugated (Jackson Immuno Research, Hamburg, Germany). Alexa Fluor 568-labelled donkey anti-goat IgG was used as secondary antibody (Molecular Probes, Leiden, The Netherlands) in immunofluorescence stainings. Biotinylated antibodies were detected with peroxidase or alkaline phosphatase-coupled Streptavidin (Jackson Immuno Research).

Tissues were fixed in $4 \%$ phosphate-buffered formaldehyde, embedded in paraffin, cut into $5-\mu \mathrm{m}$ cross sections, deparaffinized, and demasked by heat (citrate buffer, $\mathrm{pH}$ 6.0) or trypsinization (F4/80, Ly-6G). Endogenous peroxidase activity was blocked with $3 \% \mathrm{H}_{2} \mathrm{O}_{2}$ and a biotin-blocking step (Vector Laboratories, Loerrach, Germany) was performed before biotinylated antibodies were applied. Primary antibodies were incubated for $30 \mathrm{~min}-2 \mathrm{~h}$ at room temperature or at $4{ }^{\circ} \mathrm{C}$ overnight, followed by an appropriate secondary antibody or/and a streptavidin conjugate (alkaline phosphatase or horseradish peroxidase). Horseradish peroxidase activity was detected using the AEC detection system (Dako). Alkaline phosphatase activity was detected using Fast blue salt (SigmaAldrich, Munich, Germany). Periodic acid-Schiff histochemistry was conducted in a Dako Autostainer plus (Dako) according to the manufacturer's instructions.

For frozen sections, tissues were embedded in Tissue Tek OCT compound (Sakura Finetek, Staufen, Germany) and frozen on dry ice. Cryosections were cut to 5-8 $\mu \mathrm{m}$ thickness, air dried, and fixed for $10 \mathrm{~min}$ in $-20^{\circ} \mathrm{C}$ acetone. Cryosections were rehydrated in $50 \mathrm{mM}$ Tris-buffered saline, $\mathrm{pH}$ 7.6. All slides were mounted in Mowiol solution (11.7\% $\mathrm{wt} / \mathrm{vol}$ Mowiol, $29.4 \% \mathrm{wt} / \mathrm{vol}$ glycerine, $0.12 \mathrm{M}$ Tris, $\mathrm{pH}$ 8.5). Images were acquired with a Zeiss Axiophot fluorescence microscope with an Axiocam HRc camera or with an AxioImager Z1 microscope equipped with a charge-coupled device camera (AxioCam MRm) and further processed using AxioVision 4.5 software (Carl Zeiss, Jena, Germany).

The intraepithelial lymphocytes were quantified in hematoxylin and eosin-stained sections by counting the small and round lymphocytes within the basal portion of the surface epithelium per 100 epithelial cells according to a previously published standard method used in routine pathology. 51

Electrophysiological measurements. Experiments were carried out as published previously. ${ }^{24,52}$ Mouse or rat distal colon mucosa were mounted into Ussing chambers. The bathing fluid consisted of (mM): $\mathrm{Na}^{+}, 140.0$; $\mathrm{Cl}^{-}, 123.8 ; \mathrm{K}^{+}, 5.4 ; \mathrm{Ca}^{2+}, 1.2 ; \mathrm{Mg}^{2+}, 1.2 ; \mathrm{HPO}_{4}{ }^{2-}, 2.4 ; \mathrm{H}_{2} \mathrm{PO}_{4}{ }^{-}, 0.6$; $\mathrm{HCO}_{3}{ }^{-}, 21.0 ; \mathrm{D}(+)$-glucose, $10.0 ; \beta$-OH-butyrate, 0.5 ; glutamine, 2.5; and $\mathrm{D}(+)$-mannose, 10.0. The solution was equilibrated with $95 \% \mathrm{O}_{2}$ and $5 \% \mathrm{CO}_{2}$ at $\mathrm{pH} 7.4$. Temperature was kept constantly at $37^{\circ} \mathrm{C}$. To avoid bacterial growth, piperacillin $\left(50 \mathrm{mgl}^{-1}\right)$ and imipenem $\left(10 \mathrm{mgl}^{-1}\right)$ were added in experiments. Dimethyl sulfoxide and ethanol were used for solubilization of aldosterone and did not affect short-circuit current or transepithelial resistance at the concentrations used in the experiments. Piperacillin, imipenem, and dimethyl sulfoxide itself had no effect on transport and barrier parameters. The exposed tissue area was $0.049 \mathrm{~cm}^{2}$ for mouse colon and $0.54 \mathrm{~cm}^{2}$ for rat colon Ussing experiments. Voltage $(\mathrm{mV})$ and tissue resistance $\left(\mathrm{cm}^{2}\right)$ were constantly recorded and used to calculate equivalent short-circuit current $\left(I_{\text {sc }}\right)$ by Ohm's law $(I=U / R)$ using a six- or eight-channel computer-controlled voltage clamp device (CVC-6 or CVC-8, Fiebig, Berlin, Germany). In Ussing experiments using rat late distal colon for elucidation of IL-1 $\beta$-mediated signaling, inhibitors of mitogen-activated protein kinase/ERK kinase 1/2 (U0126, Cell Signaling Technology, Frankfurt am Main, Germany) and p38 mitogen-activated protein kinase (SB202190, Calbiochem, Darmstadt, Germany) were added $(10 \mu \mathrm{M})$ for $1 \mathrm{~h}$ followed by addition of rat IL-1 $\beta$ (IL-1 $\beta$, final concentration: $10 \mathrm{ng} \mathrm{ml}^{-1}, 10 \mathrm{U} \mathrm{ng}^{-1}$, Biotrend, Germany) for $6 \mathrm{~h}$ and aldosterone $\left(3 \times 10^{-9} \mathrm{M}\right.$, Sigma, Schnelldorf, Germany) for further $8 \mathrm{~h}$. The drop in $I_{\mathrm{sc}}$ after addition of amiloride $\left(10^{-4} \mathrm{M}\right.$, Sigma, Schnelldorf, Germany) was assigned to $\mathrm{ENaC}$-dependent sodium flux and is expressed as the flux of monovalent cations $\left(\mu \mathrm{molh} \mathrm{h}^{-1} \mathrm{~cm}^{-2}\right)$. 
For measuring electrogenic $\mathrm{Cl}^{-}$secretion in mouse colon, tissues were stimulated by prostaglandin $\mathrm{E}_{2}\left(2.8 \mathrm{nmoll}^{-1}\right.$, serosal side $)$ and theophylline $\left(10 \mathrm{mmoll}^{-1}\right.$, both sides $)$. The increase in $I_{\mathrm{sc}}\left(\Delta I_{\mathrm{sc}}\right)$ was measured thereafter.

Transmural impedance analysis. Transmural alternating current impedance spectroscopy was performed as described earlier. ${ }^{53}$ Briefly, mouse colon was mounted into a miniaturized Ussing chamber as described above and 48 discrete frequencies of an effective sinewave alternating current of $35 \mu \mathrm{A} \cdot \mathrm{cm}^{-2}$ were applied ranging from $1.3 \mathrm{~Hz}$ to $65 \mathrm{kHz}$. Resulting changes in tissue voltage were detected by phase-sensitive amplifiers. Calculated complex impedance values were plotted in a Nyquist diagram and fitted by least-square analysis. $R^{\mathrm{t}}$ (transepithelial resistance) was obtained at low and $R^{s}$ (subepithelial resistance) at high frequencies. $R^{\mathrm{e}}=R^{\mathrm{t}}-R^{\mathrm{s}}$, where $R^{\mathrm{e}}$ indicates epithelial resistance.

Whole-gut transit time. After a 24-h fast with access to water, $0.3 \mathrm{ml}$ of glutinous liquid, consisting of Karmin Red and 1.5\% methyl cellulose (both Sigma-Aldrich), was administered by gastric gavage. The time from administration to evacuation of dyed feces was measured.

Isolation of lamina propria leukocytes from colonic tissue. Minced tissue of murine colons was shaken in Hank's balanced salt solution (w/o $\mathrm{Mg} / \mathrm{Ca}$ ) supplemented with $5 \mathrm{mM}$ ethylenediaminetetraacetic acid and $1 \mathrm{mM}$ dithiothreitol for $30 \mathrm{~min}$ at $37^{\circ} \mathrm{C}$. Tissue debris were washed twice with RPMI 1640 medium and further digested in RPMI 1640 medium supplemented with $10 \%$ fetal calf serum, $2 \mathrm{mM}$ glutamine, $50 \mu \mathrm{M}$ $\beta$-mercaptoethanol, $0.5 \mathrm{mg} \mathrm{ml}^{-1}$ Collagenase D (Roche), and $20 \mu \mathrm{g} \mathrm{ml}^{-1}$ DNAse I for $90 \mathrm{~min}$ at $37^{\circ} \mathrm{C}$ under agitation. Single-cell suspensions were obtained by passing the enzymatic digest through a nylon mesh, followed by a Percoll density gradient centrifugation.

Flow cytometry analysis. The following primary antibodies were used: fluorescein isothiocyanate-conjugated rat anti-mouse CD69; phycoerythrin-conjugated rat anti-mouse CD44 and CD45; and allophycocyanin-conjugated rat anti-mouse CD4, CD8, and CD117 (c-kit) (all from Biolegend, Uithoorn, The Netherlands). Data were acquired on a FACS Calibur flow cytometer (BD Biosciences) and analyzed with Flowjo software version 8.8.2 (BD Biosciences).

RNA isolation, reverse transcription, and quantitative real-time PCR. Total RNA from murine colons was extracted using the RNeasy Midi Kit (Qiagen, Hilden, Germany), and RNA integrity was confirmed with an Agilent (Böblingen, Germany) Bioanalyzer system. cDNA synthesis was performed with oligo(dT) primers using the SuperScript III First-Strand Synthesis Kit (Invitrogen, Darmstadt, Germany). Reverse transcription and quantitative real-time PCR was performed using the iQ5 Real-Time PCR Detection System (BioRad, Munic, Germany). Sense (s) and antisense (as) primers were used to amplify gene-specific regions: 5' -CGGAGTTGCTAAACTCAACATC-3' (s) and $5^{\prime}$-TGGAGACCAGTACCGGCT- $3^{\prime}$ (as) for ENaC- $\alpha$; $5^{\prime}$-ATGTGGTT CCTGCTTACGCTG-3' (s) and $5^{\prime}$-GTCCTGGTGGTGTTGCTGTG-3' (as) for ENaC- $\beta$; $5^{\prime}$-CCAAAGCCAGCAAATAAACAAA- $3^{\prime}$ (s) and $5^{\prime}$-GCGGCGGGCAATAATAGAGA-3' (as) for ENaC- $\gamma ; 5^{\prime}$-TTCTTCA CGCCCCTATGTCGA-3' (s) and $5^{\prime}$-GCTCCAATCACAATGA ACACCA-3' (as) for CFTR; and 5' -TCATACTCAAGACTCCGTCC-3' (s) and $5^{\prime}$-TACCACTTGTTTCTCCGTCC-3' (as) for Villin. For data analysis, gene transcript expression was calculated relative to Villin expression in the same experiment.

Detection of autoantibodies by enzyme-linked immunosorbent assay. For the assessment of serum levels of colonic Ag-specific IgG and IgM autoantibodies, microtiter plates were coated overnight with $10 \mu \mathrm{g} \mathrm{ml}^{-1}$ whole Wt colonic tissue lysate and incubated with sera at a dilution of 1:50. Bound IgG or IgM antibodies were detected using horseradish peroxidase-conjugated rabbit-anti-mouse IgG or IgM antiserum (1:4000, Biozol, Eching, Germany) in conjunction with 3,3',5,5' tetramethylbenzidine substrate (BD Biosciences). Serum was prepared from blood obtained by cardiac puncture and stored at $-80^{\circ} \mathrm{C}$. For the preparation of colonic tissue lysate, organs were homogenized in lysis buffer containing $100 \mathrm{mM} \mathrm{KCl}, 30 \mathrm{mM} \mathrm{NaCl}, 35 \mathrm{mM} \mathrm{MgCl}_{2}, 100 \mathrm{mM}$ Pipes, $12.5 \mathrm{mM}$ EGTA, 0.5\% NP-40, and a cocktail of protease inhibitors, pH 6.8 .

Determination of secreted cytokines. Colon segments (transverse, distal) of 2-months-old mice were incubated in $500 \mu \mathrm{l}$ serum-free RPMI 1640 medium containing Pen/Strep for $22 \mathrm{~h}$ at $37^{\circ} \mathrm{C}$ and $5 \% \mathrm{CO}_{2}$. Supernatants were harvested and assayed for secreted IL-6, TNF- $\alpha$, IFN- $\gamma$, IL-4, and IL-13 using the Mouse Inflammation Cytometric Bead Array kit (BD Biosciences) and for IL-1 $\beta$ using the corresponding Flex Sets. Data were analyzed with the FCAP Array v1.0.1 software (BD Biosciences) according to the manufacturer's instructions. Cytokine concentration was indicated by the fluorescent intensity and finally normalized to colon weight. Undiluted supernatants were also assayed for secreted IL-15 using a mouse IL-15 ELISA kit (BD Biosciences). Recombinant IL-15 served as a standard and IL-15 concentrations were normalized to colonic weight.

Statistical analysis. Results are expressed as arithmetic means \pm standard deviation (s.d.) or standard error of the mean (s.e.m.), as indicated. Values of $P<0.05$ were considered statistically significant and determined either by an unpaired, two-tailed Mann-Whitney test or an unpaired, two-tailed Student's $t$ test, as indicated.

SUPPLEMENTARY MATERIAL is linked to the online version of the paper at http://www.nature.com/mi

\section{ACKNOWLEDGMENTS}

This work was funded by the Priority Program SFB 633 of the German Research Foundation (DFG) and the DFG grant SCHU 2389/1-1. We are grateful to K. Krüger, A. Fromm, B. Jebautzke, K. Räbel, and H. Schwede for excellent technical assistance. We are indebted to Armin Rehm for helpful suggestions and critical reading of the manuscript.

\section{DISCLOSURE}

The authors declared no conflict of interest.

2012 Society for Mucosal Immunology

\section{REFERENCES}

1. Brandtzaeg, P. Mucosal immunity: induction, dissemination, and effector functions. Scand J Immunol 70, 505-515 (2009).

2. Cerf-Bensussan, N. \& Gaboriau-Routhiau, V. The immune system and the gut microbiota: friends or foes? Nat Rev Immunol 10, 735-744 (2011).

3. Eberl, G. A new vision of immunity: homeostasis of the superorganism. Mucosal Immunol 3, 450-460 (2011).

4. Artis, D. Epithelial-cell recognition of commensal bacteria and maintenance of immune homeostasis in the gut. Nat Rev Immuno/ 8, 411-420 (2008).

5. Brandtzaeg, P., Kiyono, H., Pabst, R. \& Russell, M.W. Terminology: nomenclature of mucosa-associated lymphoid tissue. Mucosal Immunol 1, 31-37 (2008).

6. Forster, R. et al. CCR7 coordinates the primary immune response by establishing functional microenvironments in secondary lymphoid organs. Cell 99, 23-33 (1999)

7. Muller, G., Hopken, U.E. \& Lipp, M. The impact of CCR7 and CXCR5 on lymphoid organ development and systemic immunity. Immunol Rev 195, 117-135 (2003).

8. Hopken, U.E., Winter, S., Achtman, A.H., Kruger, K. \& Lipp, M. CCR7 regulates lymphocyte egress and recirculation through body cavities. J Leukoc Bio/ 87, 671-682 (2010).

9. Davalos-Misslitz, A.C. et al. Generalized multi-organ autoimmunity in CCR7-deficient mice. Eur J Immuno/ 37, 613-622 (2007).

10. Winter, S. et al. Manifestation of spontaneous and early autoimmune gastritis in CCR7-deficient mice. Am J Pathol 179, 754-65 (2011). 
11. Mankertz, J. \& Schulzke, J.D. Altered permeability in inflammatory bowel disease: pathophysiology and clinical implications. Curr Opin Gastroentero/ 23, 379-383 (2007).

12. Headstrom, P.D. \& Surawicz, C.M. Chronic diarrhea. Clin Gastroenterol Hepato/ 3, 734-737 (2005).

13. Binder, H.J. Causes of chronic diarrhea. N Engl J Med 355, 236-239 (2006).

14. Hopken, U.E. et al. CCR7 deficiency causes ectopic lymphoid neogenesis and disturbed mucosal tissue integrity. Blood 109, 886-895 (2007).

15. Schmitz, H. et al. Altered tight junction structure contributes to the impaired epithelial barrier function in ulcerative colitis. Gastroenterology 116, 301-309 (1999).

16. Schmitz, H. et al. Tumor necrosis factor-alpha (TNFalpha) regulates the epithelial barrier in the human intestinal cell line HT-29/B6. J Cell Sci 112 (Pt 1), 137-146 (1999).

17. Hoving, J.C. et al. B cells that produce immunoglobulin E mediate colitis in BALB/c mice. Gastroenterology 142, 96-108 (2012).

18. Eberl, M. et al. Microbial isoprenoid biosynthesis and human gammadelta T cell activation. FEBS Lett 544, 4-10 (2003).

19. Hofmann, A.M. \& Abraham, S.N. New roles for mast cells in modulating allergic reactions and immunity against pathogens. Curr Opin Immunol 21, 679-686 (2009).

20. Galli, S.J., Grimbaldeston, M. \& Tsai, M. Immunomodulatory mast cells: negative, as well as positive, regulators of immunity. Nat Rev Immuno/ 8 , 478-486 (2008).

21. Araki, Y., Andoh, A., Fujiyama, Y. \& Bamba, T. Development of dextran sulphate sodium-induced experimental colitis is suppressed in genetically mast cell-deficient Ws/Ws rats. Clin Exp Immunol 119, 264-269 (2000).

22. Hue, S. et al. A direct role for NKG2D/MICA interaction in villous atrophy during celiac disease. Immunity 21, 367-377 (2004).

23. Mention, J.J. et al. Interleukin 15: a key to disrupted intraepithelial lymphocyte homeostasis and lymphomagenesis in celiac disease. Gastroenterology 125, 730-745 (2003).

24. Barmeyer, C. et al. IL-1 beta and TNFalpha regulate sodium absorption in rat distal colon. Biochem Biophys Res Commun 317, 500-507 (2004).

25. Barmeyer, C. et al. Mechanisms of diarrhea in the interleukin-2-deficient mouse model of colonic inflammation. Am J Physiol Gastrointest Liver Physio/ 286, G244-252 (2004).

26. Schulzke, J.D., Andres, S., Amasheh, M., Fromm, A. \& Gunzel, D. Anti-diarrheal mechanism of the traditional remedy Uzara via reduction of active chloride secretion. PLoS One 6, e18107 (2011).

27. Zeissig, S. et al. Altered ENaC expression leads to impaired sodium absorption in the noninflamed intestine in Crohn's disease. Gastroenterology 134, 1436-1447 (2008).

28. Roux, J. et al. Interleukin-1 beta decreases expression of the epithelial sodium channel alpha-subunit in alveolar epithelial cells via a p38 MAPKdependent signaling pathway. J Biol Chem 280, 18579-18589 (2005).

29. Autenrieth, I.B., Bucheler, N., Bohn, E., Heinze, G. \& Horak, I. Cytokine mRNA expression in intestinal tissue of interleukin-2 deficient mice with bowel inflammation. Gut 41, 793-800 (1997).

30. MacDermott, R.P. \& Stenson, W.F. Alterations of the immune system in ulcerative colitis and Crohn's disease. Adv Immunol 42, 285-328 (1988).

31. Sartor, R.B. Pathogenetic and clinical relevance of cytokines in inflammatory bowel disease. Immunol Res 10, 465-471 (1991).

32. Brombacher, F. The role of interleukin-13 in infectious diseases and allergy. Bioessays 22, 646-656 (2000).
33. Musch, M.W. et al. T cell activation causes diarrhea by increasing intestinal permeability and inhibiting epithelial $\mathrm{Na}+/ \mathrm{K}+-$ ATPase. J Clin Invest 110, 1739-1747 (2002).

34. Suenaert, P. et al. Effects of T cell-induced colonic inflammation on epithelial barrier function. Inflamm Bowel Dis 16, 1322-1331 (2011).

35. Perera, L.P. Interleukin 15: its role in inflammation and immunity. Arch Immunol Ther Exp (Warsz) 48, 457-464 (2000).

36. Obermeier, F. et al. IL-15 protects intestinal epithelial cells. Eur J Immunol 36, 2691-2699 (2006).

37. Coombes, J.L., Robinson, N.J., Maloy, K.J., Uhlig, H.H. \& Powrie, F. Regulatory T cells and intestinal homeostasis. Immunol Rev 204, 184-194 (2005).

38. Izcue, A., Coombes, J.L. \& Powrie, F. Regulatory lymphocytes and intestinal inflammation. Annu Rev Immunol 27, 313-338 (2009).

39. Murai, M., Krause, P., Cheroutre, H. \& Kronenberg, M. Regulatory T-cell stability and plasticity in mucosal and systemic immune systems. Mucosal Immuno/ 3, 443-449 (2011).

40. Garty, H. \& Palmer, L.G. Epithelial sodium channels: function, structure, and regulation. Physiol Rev 77, 359-396 (1997).

41. Amasheh, S. et al. Cytokine-dependent transcriptional down-regulation of epithelial sodium channel in ulcerative colitis. Gastroenterology 126, 1711-1720 (2004).

42. Bergann, T. et al. Glucocorticoids and tumor necrosis factor-alpha synergize to induce absorption by the epithelial sodium channel in the colon. Gastroenterology 136, 933-942 (2009).

43. Choi, J.Y. et al. Interleukin-1 beta suppresses epithelial sodium channel beta-subunit expression and ENaC-dependent fluid absorption in human middle ear epithelial cells. Eur J Pharmaco/ 567, 19-25 (2007).

44. Cafferata, E.G., Gonzalez-Guerrico, A.M., Giordano, L., Pivetta, O.H. \& Santa-Coloma, T.A. Interleukin-1 beta regulates CFTR expression in human intestinal T84 cells. Biochim Biophys Acta 1500, 241-248 (2000).

45. Andus, T. et al. Imbalance of the interleukin 1 system in colonic mucosaassociation with intestinal inflammation and interleukin 1 receptor antagonist [corrected] genotype 2. Gut 41, 651-657 (1997).

46. Hoffman, H.M. \& Wanderer, A.A. Inflammasome and IL-1 beta-mediated disorders. Curr Allergy Asthma Rep 10, 229-235 (2011).

47. Gattorno, M. et al. Differentiating PFAPA syndrome from monogenic periodic fevers. Pediatrics 124, e721-728 (2009).

48. Akiho, H., Ihara, E., Motomura, Y. \& Nakamura, K. Cytokine-induced alterations of gastrointestinal motility in gastrointestinal disorders. World J Gastrointest Pathophysiol 2, 72-81 (2011).

49. Gan, H.T. \& Chen, J.D. Induction of heme oxygenase-1 improves impaired intestinal transit after burn injury. Surgery 141, 385-393 (2007).

50. Nakao, A. et al. Immunomodulatory effects of inhaled carbon monoxide on rat syngeneic small bowel graft motility. Gut 52, 1278-1285 (2003).

51. Dixon, M.F., Genta, R.M., Yardley, J.H. \& Correa, P. Classification and grading of gastritis. The updated Sydney System. International Workshop on the Histopathology of Gastritis, Houston 1994. Am J Surg Pathol 20, 1161-1181 (1996).

52. Kroesen, A.J. et al. Impairment of epithelial transport but not of barrier function in idiopathic pouchitis after ulcerative colitis. Gut 50, 821-826 (2002).

53. Troeger, H. et al. Effect of chronic Giardia lamblia infection on epithelial transport and barrier function in human duodenum. Gut 56, 328-335 (2007). 